Ann. Biol. anim. Bioch. Biophys., I976, 16 (6), 833-849.

\title{
THE ROLE OF EXOGENOUS OXYTOCIN IN LACTATING EWE
}

\author{
J. MARTINET*, M. MORAG** (1) and R. DENAMUR* ( $\left.{ }^{(}\right)$ \\ * Laboratoire de Physiologie de la Lactation, I. N. R. A., \\ 78350 Jouy en Josas (France) \\ ** Institute for Research in Arid Zone, \\ Beersheva, Israel
}

\begin{abstract}
SUMMARY
The effect of exogenous oxytocin on milk yield is studied in a series of experiments on the dairy ewe.

Experiments $I$ and $I I$. A non-galactokinetic dose (o.oI and $0.05 \mathrm{IU} / \mathrm{hr}$ ) injected into the carotid artery did not change milk yield. The results do not seem to confirm central oxytocin action on the lactogenic hormonal complex of the hypophysis.

Experiments III, IV,V. IV injection of oxytocin (o.I to $2 \mathrm{IU}$ ) only had a tonic effect on milk yield when followed by extraction of the residual milk produced.

Experiments $I I I, I V, V I$ and $V I I$. The tonic effect of oxytocin on milk secretion is confirmed even when it is injected IV in high doses (O.I to Io IU) after each milking. At the same time, oxytocin is also shown to have an inhibitory effect on natural milk ejection
\end{abstract}

Repeated injections of oxytocin stimulate milk secretion in small ruminants. When this hormone is injected milk yield increases by Io to $40 \mathrm{p}$. IOo in goats (DENAMUR, I953; LINZELL and PEAKER, I97I $a$ ) and ewes (DENAMUR and MARTINET, r96I; MORAG and Fox, I966; MORAG, I968 $a, b$ ). The oxytocin stimulation mechanism of milk secretion has not yet been clearly defined, but might operate in one of the ways described below.

\section{Central oxytocin stimulation}

Oxytocin may act directly on the hypothalamus or the anterior pituitary gland. BENSON and FOLLEY (I956, I957) suggested that oxytocin elicits a release of prolactin from the latter gland. This idea was not confirmed by MEITES (I958), MEITES and Nicoli (I959) or DeNamur and MARTINET (I96I), although the oxytocin doses

(1) Deceased in 1973 . 
injected were relatively high. It was recently supported by BRYANT et al. (Ig68, 1970). Prolactin alone does not seem to be the most lactogenous hormone in the ewe (Denamur and Maritinet, I970).

\section{Local mammary action}

Ejection of milk from the alveoli into the ducts and sinuses without removal of residual milk

Oxytocin injected between milkings in the cow (MORAG, Ig68 b) or suckling in the rat (MORAG and BRICK, I969) caused large increases of milk yield. The temporary relief of alveolar pressure may stimulate milk secretion.

\section{Ejection and removal of residual milk}

The removal of residual milk with various doses of oxytocin increases milk yield in cows (see review by ElLIOT, I969; MORAG, I967) and sheep (DENAMUR and MARTINET, I96I ; MoRAG and Fox, I966; MoraG, Ig68 a). Hourly milking with an exogenous supply of physiological levels of oxytocin increases milk yield in goats (LINZELL, and PEAKER, I97I $a, b$ ).

Direct metabolic effect on the secretory tissue

Glucose metabolism of mammary slices is stimulated by large doses of oxytocin (GOOdFriend and Topper, I96I ; Cohen, BRenNeman and Topper, I962).

\section{Changes in mammary gland permeability}

Changes in the electrolyte concentration of milk following the administration of oxytocin have been observed in cows (MCKENZIE and LASCELLES, I965; WHEELOCK et al., I966 ; MORAG, I968 b) and goats (KNUTTSON, I96I ; LINZELL and PEAKER, I97I c).

\section{Removal of a chemical substance}

This substance has a negative feedback effect on milk synthesis or a metabolic action on hormonal release (LINZELL, and PEAKER, I97I $a ; L_{\text {ENVY, }}$ 1963).

We shall describe a series of experiments on dairy ewes using various experimental designs to formulate an approach to the study of the effect of oxytocin on milk secretion.

\section{A. - INVESTIGATIONS ON CENTRAI, MODE OF ACTION}

\section{Experiments $I$ and $I I$}

In two experiments non-galactokinetic doses of oxytocin were injected (MaRTINET and DENAMUR, I960). Experimental designs and results are presented in tables I and 2. In our experimental conditions (oxytocin doses used and length of the experiment) we were unable to change the milk secretion level of ewes by direct. oxytocin action on the release mechanism of the lactogenous complex. 
TABLE I

Experiment I

Experimental design and treatment definitions

\begin{tabular}{|c|c|c|c|c|}
\hline & \multirow{2}{*}{ Latin square } & \multicolumn{3}{|c|}{ Periods } \\
\hline & & I & II & III \\
\hline 6 ewes & $\ldots \ldots \ldots \ldots \ldots \ldots$ & A & $\mathbf{B}$ & C \\
\hline 6 ewes & $\ldots \ldots \ldots \ldots \ldots$ & C & $\mathbf{A}$ & $\mathrm{B}$ \\
\hline 6 ewes & $\ldots \ldots \ldots \ldots$ & $\mathrm{B}$ & $\mathrm{C}$ & A \\
\hline
\end{tabular}

Each period lasted 3 days $(6 \times 12 \mathrm{~h}$ milking intervals), hand milked ewes weaned after lambing.

\section{Treatment definitions}

A. Intra-carotid infusion of $0.01 \mathrm{IU}$ oxytocin in $8 \mathrm{ml} / \mathrm{h}$ of $0.9 \mathrm{p} .100$ saline.

B. Intra-carotid infusion of $8 \mathrm{ml} / \mathrm{h}$ of $0.9 \mathrm{p} .100$ saline.

C. Intra-jugular infusion of $0.01 \mathrm{IU}$ oxytocin in $8 \mathrm{ml} / \mathrm{h}$ of $0.9 \mathrm{p} .100$ saline.

Treatment results

Intra-carotid oxytocin $\quad 717.8 \mathrm{~g}$ of milk/day

Intra-carotid saline

Intra-jugular oxytocin

679.4

705.7

Standard error of the mean

$20.1 \quad-$

TABLE 2

Experiment II

Experimental design and treatment definitions

\begin{tabular}{|c|c|c|}
\hline \multirow{2}{*}{ Change-over design } & \multicolumn{2}{|c|}{ Periods } \\
\hline & I & II \\
\hline 6 ewes $\ldots \ldots \ldots \ldots \ldots$ & A & B \\
\hline 6 ewes $\ldots \ldots \ldots \ldots \ldots \ldots$ & $\mathbf{B}$ & $\mathbf{A}$ \\
\hline
\end{tabular}

Each period lasted 5 days $(10 \times 12 \mathrm{~h}$ milking intervals).

\section{Treatment definitions}

A. Intra-carotid infusion of 0.05 IU oxytocin in $6 \mathrm{ml} / \mathrm{h}$ of $0.9 \mathrm{p} .100$ saline.

B. Intra-carotid infusion of saline $6 \mathrm{ml} / \mathrm{h}$.

Results

\begin{tabular}{|c|c|c|c|}
\hline Source of variation & d.f. & $\mathrm{F}$ & Significance \\
\hline Days $\ldots . \ldots \ldots \ldots$ & 4 & 0.65 & NS \\
\hline Periods I, II . . . . . . . . . & 1 & 4.91 & $0.01<\mathrm{P}<0.05$ \\
\hline Treatment $\ldots \ldots \ldots \ldots \ldots$ & 1 & 0.09 & NS \\
\hline Group (low-medium-high) .. & 2 & 65.5 & $\mathrm{P}<0.01$ \\
\hline
\end{tabular}

All the interactions are non significant

\begin{tabular}{c|c}
\hline Treatments & Means-daily milk yield \\
\hline Intracarotid infusion of $0.05 \mathrm{IU} / \mathrm{h} \ldots \ldots \ldots \ldots$ & $\begin{array}{r}686.7 \mathrm{~g} \\
676.9 \mathrm{~g}\end{array}$ \\
\hline
\end{tabular}




\section{B. - INVESTIGATIONS ON LOCAL MAMMARY ACTION}

\section{Experiment $I I I$ : Oxytocin injected between milkings}

Animals were milked by machine and hand-stripped. Residual milk fraction was removed by hand in two stages, each preceded by an injection of $0.5 \mathrm{IU}$ oxytocin injected by jugular cannula (Table 3 ). The results were analyzed in a split-plot design.

TABLE 3

Experiment III

Experimental design and treatment definitions

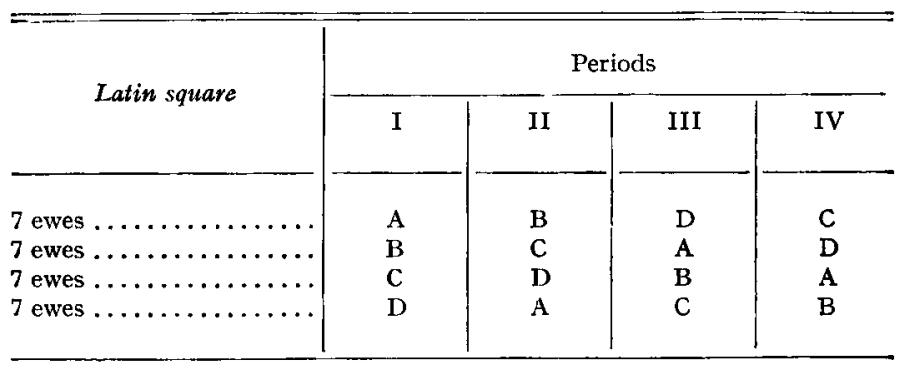

Treatment definitions

Main plot treatments :

A. 0.25 IU oxytocin given every $h$ between milkings.

B. 0.25 IU oxytocin given every $2 \mathrm{~h}$ between milkings.

C. $0.25 \mathrm{IU}$ oxytocin given every $4 \mathrm{~h}$ between milkings,

D. No hormone given between milkings.

Suis-plot treatments : Milking interval sequence (in $h$ ) within each period 12* $8^{* *} 12^{*} 12^{* *} 12^{*} 16^{* *}$ (Total $72 \mathrm{~h}$ ).

* Night standard preceding interval.

** Day treatment interval.

The main and sub-plot means and significant measurements relevant to the treatment (day intervals, table 4 ; night intervals, table 5) are shown. Results are expressed in gram of milk per hour.

Injections of oxytocin did not significantly affect milk secretion level in the day or night intervals. Yield fractionation was affected ; more frequent oxytocin injection increased the absolute and relative size of the residual fraction. Machine milk comparison can be made on an hourly milk yield basis, whereas it is difficult to use the same type of comparison for hand-stripping and residual milk. Most of the machine milk corresponds to secretion stored owing to extensibility of mammary gland storage volumes, and residual milk is the milk retained by capillarity after milking phenomenon in the mammary gland. However, while the milk yield is expressed in total amount of milk secreted (table 6), the amount of residual milk does not depend on total milk production, i.e. when the interval between milkings becomes longer, residual milk increases little but total milk is twice as high. The residual milk decreases from 30 to $22 \mathrm{p}$. Ioo of the total milk. This amount of residual milk appears to 
TABLE 4

Experiment III : Day treatment interval

Results expressed in $g$ of milk per hour

\begin{tabular}{|c|c|c|c|c|c|c|}
\hline Oxytocin injection & Total milk & Machine milk & $\begin{array}{c}\text { Hand } \\
\text { stripping }\end{array}$ & $\begin{array}{l}\text { Residual } \\
\text { milk I }\end{array}$ & $\begin{array}{l}\text { Residual } \\
\text { milk II }\end{array}$ & $\begin{array}{l}\text { Residual } \\
\text { milk }(\%)\end{array}$ \\
\hline Every hour $\ldots \ldots \ldots$. & 32,07 & 19.88 & 2.64 & 7.49 & 2.06 & 30 \\
\hline Every two hours .... & $\mathbf{3 1 . 9 7}$ & 19.96 & 3.28 & 6.91 & 1.81 & 28 \\
\hline Every 4 hours $\ldots .$. & 31.21 & 20.65 & 3.35 & 5.86 & 1.34 & 23 \\
\hline No injection ....... & 30.89 & 20.93 & 2.78 & 5.66 & 1.51 & 24 \\
\hline Mean $\ldots \ldots \ldots \ldots$ & 31.54 & 20.36 & 3.01 & 6.48 & 1.68 & 26 \\
\hline
\end{tabular}

TABLE 5

Experiment III : Night control interval

Results expressed in $g$ of milk per hour

\begin{tabular}{|c|c|c|c|c|c|c|}
\hline $\begin{array}{c}\text { Oxytocin injection } \\
\text { during the day interval }\end{array}$ & Total milk & $\begin{array}{l}\text { Machine } \\
\text { milk }\end{array}$ & $\begin{array}{c}\text { Hand } \\
\text { stripping }\end{array}$ & $\begin{array}{l}\text { Residual } \\
\text { milk I }\end{array}$ & $\begin{array}{l}\text { Residual } \\
\text { milk II }\end{array}$ & $\begin{array}{l}\text { Residual } \\
\text { milk }(\%)\end{array}$ \\
\hline Every hour .......... & 33.07 & 21.19 & 2.86 & 6.97 & 2.04 & 27.9 \\
\hline Every two hours . . . . . . . & 33.19 & 21.68 & 3.02 & 6.94 & 1.54 & 26.3 \\
\hline Every 4 hours ......... & 31.84 & 22.40 & 3.12 & 5.58 & 1.28 & 21.6 \\
\hline No injection $\ldots \ldots \ldots \ldots$ & 32.57 & 22.33 & 2,80 & 5.34 & 1.37 & 21.4 \\
\hline Mean $\ldots \ldots \ldots \ldots \ldots$ & 32.62 & 21.89 & 2.95 & 6.21 & 1.56 & 24.3 \\
\hline
\end{tabular}

TABI,E 6

Experiment III

Total milk yield (ml)

a) Experimental period (day interval $12 \mathrm{~h}$ )

\begin{tabular}{l|c|c|c|c}
\hline $\begin{array}{c}\text { Frequency of oxytocin } \\
\text { injection }\end{array}$ & $\begin{array}{c}\text { Total yield } \\
12 \mathrm{~h}\end{array}$ & Machine milk & Hand stripping & Residual milk \\
\hline Every $\mathrm{h} \ldots \ldots \ldots \ldots \ldots \ldots$ & 383 & 239 & 31 & 39 \\
Every $2 \mathrm{~h} \ldots \ldots \ldots \ldots \ldots$ & 383 & 243 & 413 \\
Every $4 \mathrm{~h} \ldots \ldots \ldots \ldots \ldots$ & 373 & 251 & 31 & 82 \\
No injection $\ldots \ldots \ldots \ldots \ldots$ & 371 & 268 & & 72 \\
\hline
\end{tabular}

b) Inter experimental period (night interval $12 \mathrm{~h}$ )

\begin{tabular}{|c|c|c|c|c|}
\hline $\begin{array}{l}\text { Control period after } \\
\text { injection }\end{array}$ & & & & \\
\hline $\begin{array}{l}\text { Every } h \quad \ldots \ldots \ldots \ldots \\
\text { Every } 2 \mathrm{~h} \ldots \ldots \ldots \ldots \\
\text { Every } 4 \mathrm{~h} \ldots \ldots \ldots \ldots \\
\text { No injection } \ldots \ldots \ldots \ldots\end{array}$ & $\begin{array}{l}397 \\
398 \\
382 \\
391\end{array}$ & $\begin{array}{l}255 \\
260 \\
263 \\
278\end{array}$ & $\begin{array}{l}34 \\
36 \\
37 \\
33\end{array}$ & $\begin{array}{r}108 \\
102 \\
82 \\
80\end{array}$ \\
\hline
\end{tabular}


be closely related to the frequency of oxytocin injections between milkings. Expression of amounts of the milk as an index (fig. I) shows inhibition of milk ejection related to frequency of oxytocin injections.
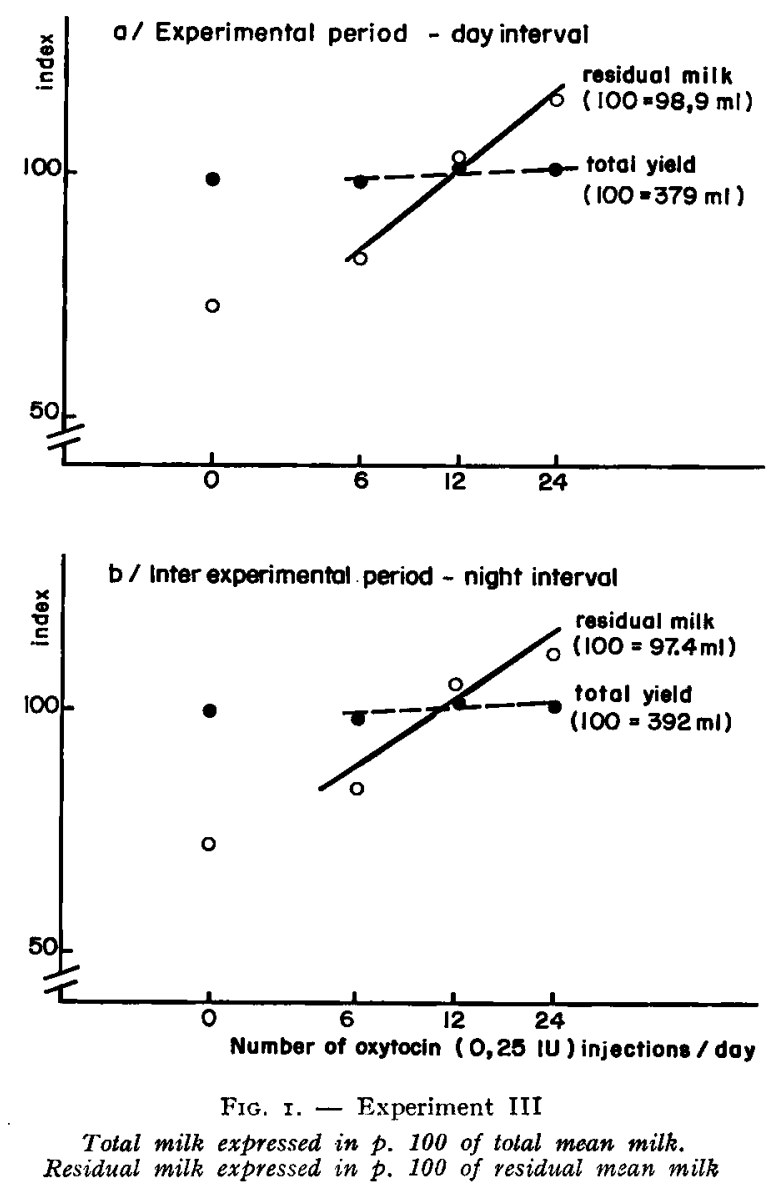

Experiment IV : Normal milk ejection

and subsequent removal of residual milk after oxytocin injection

The effect of the regular removal of residual milk with oxytocin was studied on Préalpes ewes. Increasing doses of oxytocin and saline control were injected intravenously after every milking to 6 groups of ewes for 22 weeks after parturition.

Saline control group $\ldots \ldots \ldots . \quad$ I 8 ewes

$0 . I$ IU oxytocin $\ldots \ldots \ldots \ldots \ldots .6$.

$0.5 \mathrm{IU}$ oxytocin $\ldots \ldots \ldots \ldots \ldots .6$.

I IU oxytocin $\ldots \ldots \ldots \ldots \ldots \ldots$. 20 -

2 IU oxytocin ..............

$5 \mathrm{IU}$ oxytocin $\ldots \ldots \ldots \ldots \ldots .6$. 
'The ewes were weaned 3 days after lambing; the group receiving I IU was divided into two sub-groups-ewes with a single lambing and those with twins; all ewes were machine-milked and hand-stripped. Oxytocin was then injected intravenously and the residual milk removed by hand.

The effect of oxytocin levels injected on milk yield and fractionation is shown in figure 2. There was a significant increase $(P<0.0 I)$ in milk yield when the oxytocin dose rose to I IU and 2 IU. The amounts of milk removed by machine milking and hand-stripping were unaffected, and only the increase in the residual fraction accounted for the increase in total milk.

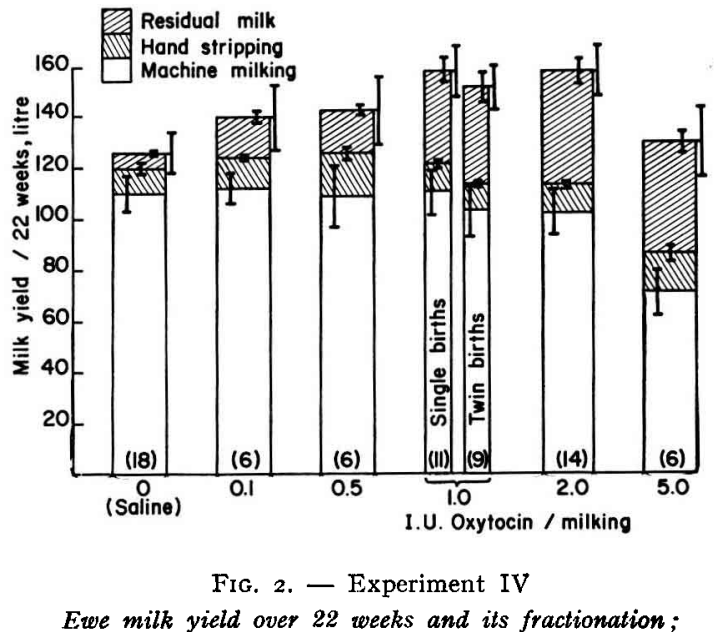

animals received increasing doses of oxytocin; standard errors are shown by feathering

The bracketed numbers indicate the number of ewes in each group

This confirms that the residual milk depends mainly on the amount of oxytocin injected between milkings (non-extracted ejected milk, Experiment III) or at milking (Experiment IV). The amount of residual milk is higher with increasing doses of oxytocin. This increase seems to have a favorable effect on total milk secretion up to I to 2 IU after each milking. When higher doses are given milk secretion is inhibited.

The interpretation of these results in terms of oxytocin stimulation of milk yield must take into account earlier evidence on the milk ejecting action of a similar dose range in Préalpes ewes. When Denamur and Martinet (I96I) injected oxytocin once $a$ week the percentage of residual milk increased from Io to $13 \mathrm{p}$. Ioo. The percentage of residual milk in the present study increased from II to $28 \mathrm{p}$. Ioo as the dose increased from o.I to I IU. The difference between these two increases of oxytocic residual milk may be considered as a measurement of the tonic effect of oxytocin on milk secretion. Thus, its injection at each milking must be followed by milk extraction. When ewes were milked there was no difference in yield and fractionation between those which had singles and those which had lambed twins (I IU treatment group). 


\section{Experiment $V:$ Effect of oxytocin extraction of residual milk compared to effect of the same treatment without removal of residual milk}

Using the half-udder technique thirteen weaned Préalpes ewes were divided into two groups containing 6 and 7 animals, respectively. They were milked for 22 weeks after lambing with a machine permitting separate milk collection from each half-udder. The first group $(\mathrm{O})$ was given a I IU injection of oxytocin while the second group (S) received a saline injection. Residual milk was obtained by hand from the right udder halves in both groups (RO and RS). The left udder halves (LO and LS) were not milked further.

The effects of oxytocin and residual milk removal are presented in figure 3 . Removing residual milk with oxytocin increased the milk yield by 36 p. roo $(P<$ o.or). The saline treatment did not significantly affect milk yield (see figure 3 for total LS and RS yields). The overall amount of machine milk appeared lower in the group which received oxytocin as compared to the one receiving only saline. This experiment confirms that oxytocin injection only affects the total amount of milk collected if followed by milking. On the other hand the RO machine milking fraction was 25 p. Ioo lower $(P<$ o.or $)$ than the RS fraction. Exogenous crxytocin seemed to inhibit natural ejection as in the previous experiments.

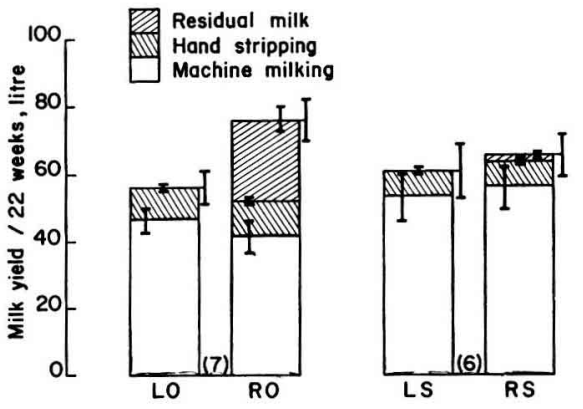

Fig. 3. - Experiment V

Ewe milk yield over 22 weeks from left (L) and right (R) half udder.

Residual milk was removed in the right half and not in the left.

The two groups either received saline (S) or oxytocin (O) injeciions.

Standard errors are shown by feathering; bracketed numbers indicate the number of ew'es in each group

\section{C. - EFFECT OF OXY'TOCIN ON MILK EJECTION}

During these experiments and in other works published previously (MoRAG and Fox, I966 ; MORAG, I968), it was clear that regular dose of oxytocin given between or at milkings reduced the amount of machine milk and increased the relative size of the strippings and residual fractions.

Unpublished work on Préalpes ewes showed that lactation ceased after high oxytocin doses were given. Thus, two more experiments were carried out to investigate the effect of these doses on milk secretion and yield and to examine eventual milk ejection inhibition by exogenous oxytocin. 


\section{Experiment $V I$}

Twenty-four mutton breed ewes (Dorset horn $\times$ Border Leicester and Cheviot) were injected with 240 IU oxytocin per day for Io days given every 4 hours in doses of 40 IU injected intravenously. Milking intervals of $8, I 2$ and I6 hours were applied, using a fully randomized design. After machine milking and hand-stripping residual milk was removed twice after an injection of 2.5 IU oxytocin each time. The results are shown in table 7. Milk yield increased about $30 \mathrm{p}$. Ioo over the Io-day period. The increase was greater during the first 5 days than during the second 5 days of treatment. The size of the residual fraction augmented in all three intervals as the experiment progressed. The relative size of this fraction decreased within a given stage as the interval increased.

TABLE 7

Experiment VI

Effect of very high doses of oxytocin (240 IU/day) on milk yield and on the percentage of residual milk of English mutton breed ewes

\begin{tabular}{|c|c|c|c|c|c|c|}
\hline & \multicolumn{2}{|c|}{ Day 1} & \multicolumn{2}{|c|}{ Day 5} & \multicolumn{2}{|c|}{ Day 10} \\
\hline & $\begin{array}{l}\text { Milk yield } \\
\mathrm{g} / \mathrm{h}\end{array}$ & $\begin{array}{l}\text { Residual } \\
\text { milk (\%) }\end{array}$ & $\begin{array}{l}\text { Milk yield } \\
\mathrm{g} / \mathrm{h}\end{array}$ & $\begin{array}{l}\text { Residual } \\
\text { milk (\%) }\end{array}$ & $\begin{array}{l}\text { Milk yield } \\
\mathrm{g} / \mathrm{h}\end{array}$ & $\begin{array}{l}\text { Residual } \\
\text { milk (\%) }\end{array}$ \\
\hline $8 \mathrm{~h}$ interval $\ldots \ldots$ & 38.4 & 37 & 53.6 & 58 & 55.2 & 64 \\
\hline $12 \mathrm{~h}$ interval ...... & 39.9 & 26 & 54.1 & 46 & 54.1 & 52 \\
\hline $16 \mathrm{~h}$ interval $\ldots \ldots$ & 39.1 & 20 & 53.9 & 33 & 54.3 & 39 \\
\hline $\begin{array}{l}\text { Standard error of the } \\
\text { mean } \ldots \ldots \ldots \ldots\end{array}$ & 2.61 & 2.8 & 2.54 & 3.9 & 3.10 & 4.0 \\
\hline
\end{tabular}

\section{Experiment VII}

A further experiment on the effect of high doses of oxytocin on milk yield and fractionation was carried out on Io Préalpes ewes (experimental design in table 8). Values of the experimental period were compared with the means in periods I and II. A significant increase in total milk yield during the treatment period was observed (fig. 4 and 5). This increase was mainly due to the large amount of residual milk secreted after oxytocin injection.

Analysis of flow rate recordings during milking shows that machine milk significantly decreases in all cases (fig. 6), but that when the three periods are compared, natural ejection represented by the second peak (LABUSSIÈRE et al., I969) is undisturbed. On the other hand, when we compare the second peak yield of the first control period with the same fraction of the experimental period we see that this parameter decreased from $I 68 \mathrm{ml}$ to $I 33 \mathrm{ml}$ in the Io IU group. This fact confirms an inhibiting milk ejection effect of high doses of oxytocin. The amount of cisternal 
TABLE 8

Experiment VII

Experimental design and treatment definitions

\begin{tabular}{c|c|c|c}
\hline & \multicolumn{3}{|c}{ Periods } \\
\cline { 2 - 3 } & $\begin{array}{c}\text { I } \\
\text { (4 days) }\end{array}$ & $\begin{array}{c}\text { II } \\
\text { (22 days) }\end{array}$ & $\begin{array}{c}\text { III } \\
\text { (6 days) }\end{array}$ \\
\hline 5 ewes $\ldots \ldots \ldots \ldots$ & $\mathrm{M}$ & $\mathrm{A}$ & $\mathrm{M}$ \\
5 ewes $\ldots \ldots \ldots \ldots$ & $\mathrm{M}$ & $\mathrm{B}$ & $\mathrm{M}$ \\
\hline
\end{tabular}

Treatment definitions

M. Machine milking and hand stripping (no oxytocin).

A. Machine milking and hand stripping followed by an injection of $5 \mathrm{IU}$ of oxytocin and the removal of residual milk.

B. Machine milking and hand stripping followed by an injection of $10 \mathrm{IU}$ of oxytocin and the removal of residual milk.

The daily flow rate of machine milk was determined during morning milking using the device described by LABUSSì̀re and MARTinet (1964). Milking was carried out twice daily after 8 and 16 hours intervals.

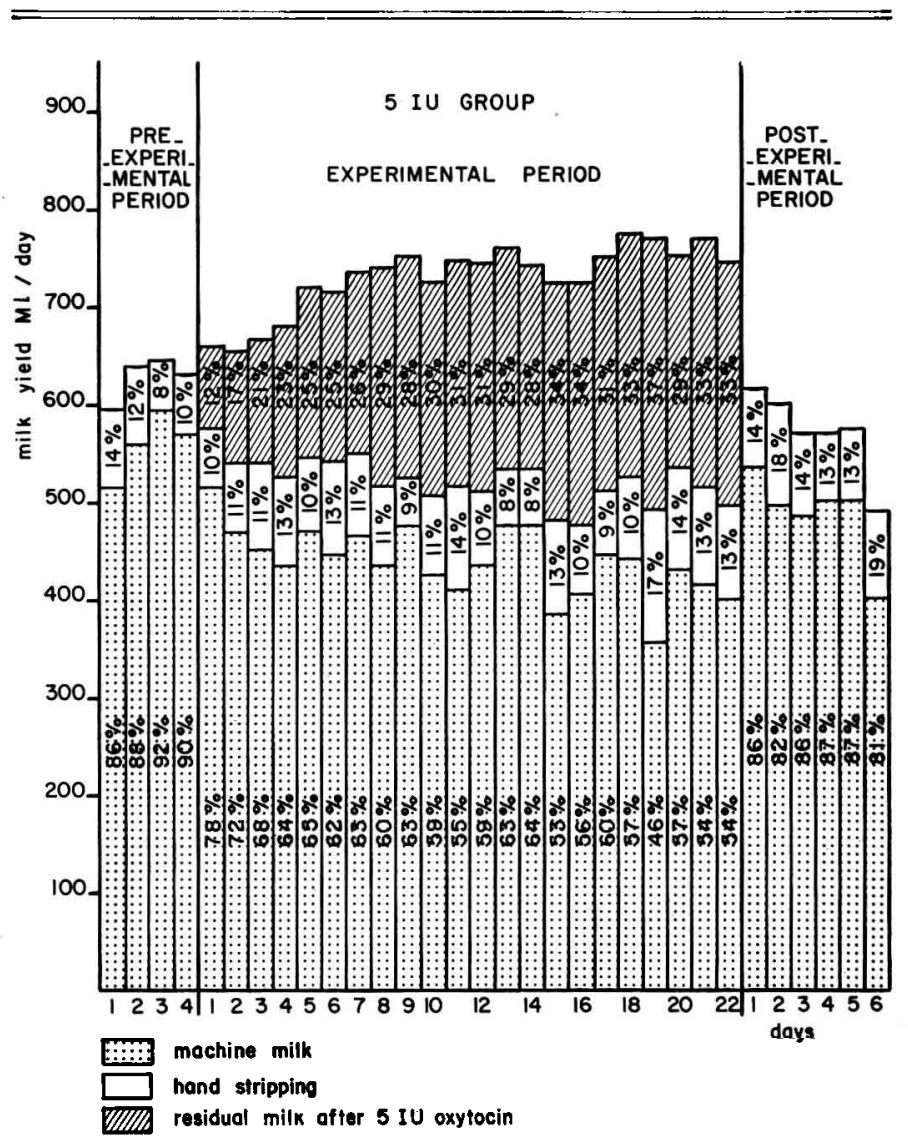

FIg. 4. - Experiment VII

Total milk yield and its fractionation. 's $I U$ oxytocin given intravenously after each milking followed by removal of residual milk 
milk (first peak) decreased in both groups. Overall comparison (table 9) shows no significant differences between the total yields of the two treatment levels ( 5 and Io IU). When the treatment period was compared with the control period, highly significant increases in milk yield were found in both groups.

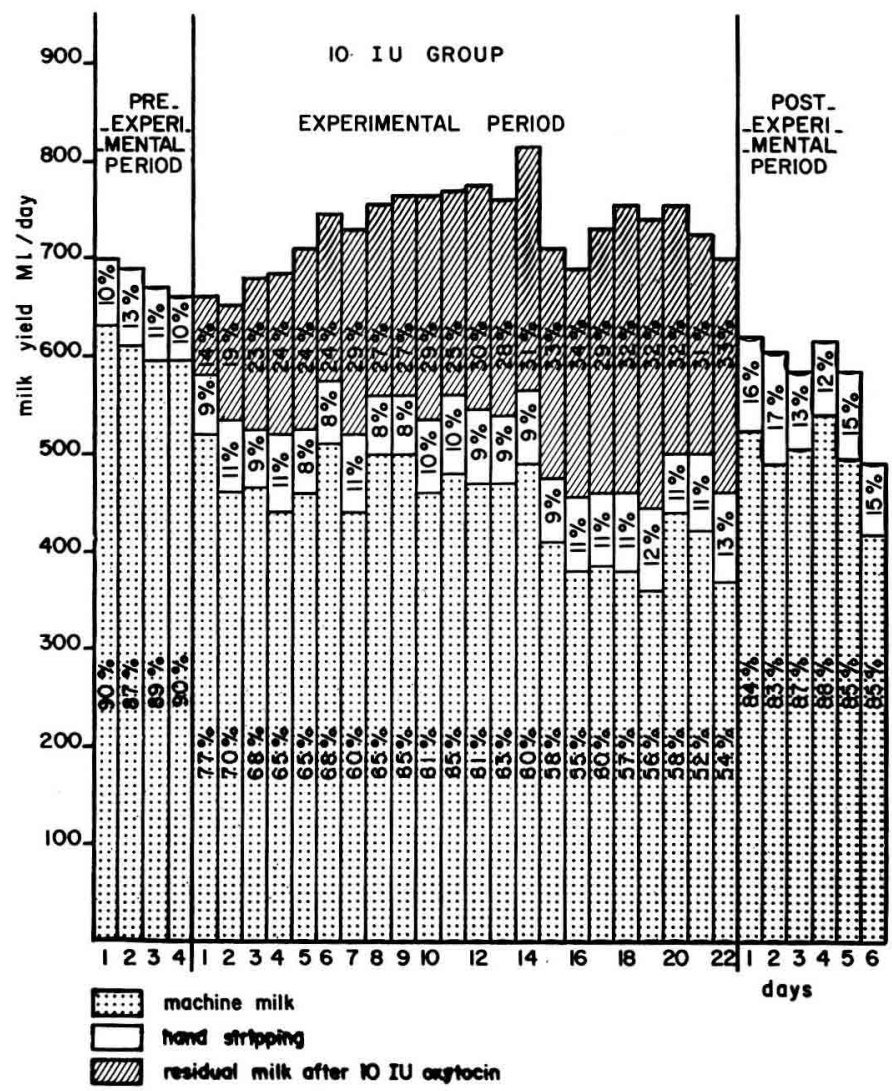

FIG. 5. - Experiment VII

Total milk yield and its fractionation. $10 \mathrm{IU}$ oxytocin given intravenously after each milking followed by removal of residual milk

\section{DISCUSSION}

\section{Is there central oxytocin action}

It was difficult to demonstrate central oxytocin effect on milk secretion in vivo. Previous experiments had showed that hormonal milk ejecting activity could mask a possible central effect. For this reason doses of oxytocin too low for milk ejection were infused (intra carotid) into lactating ewes (Experiments I and II).

No changes in milk secretion were observed; we were unable to show central 


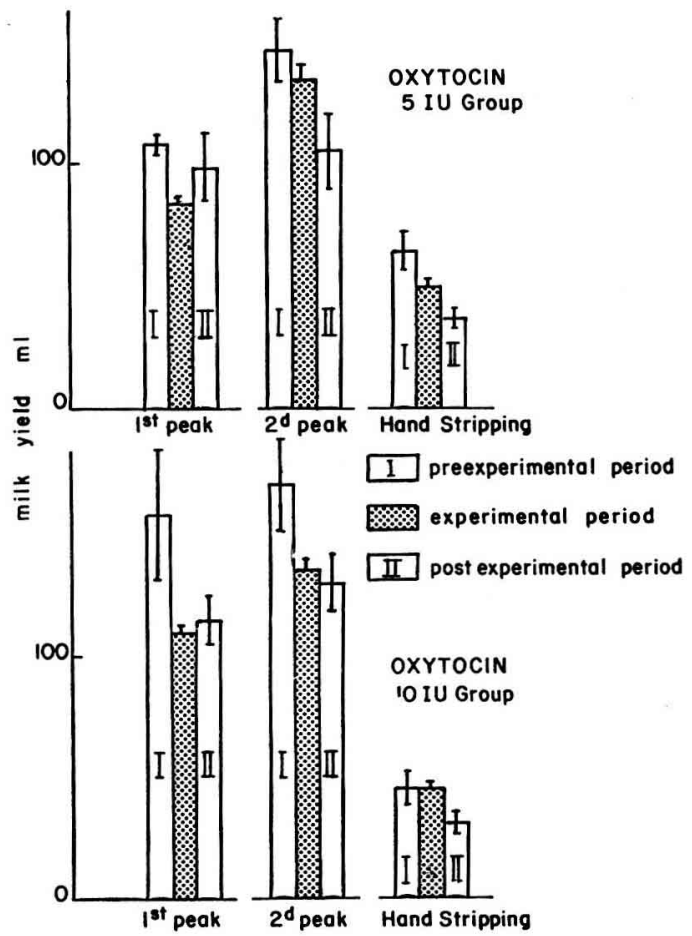

FrG. 6. - Intravenous injection of high doses (5-ro IU) of oxytocin after each milking followed by extraction of residual milk Effect on distribution of milk obtained try milking.

First peak : milk present in the mammary cistern Second peak : milk obtained by natural ejection

\section{TABLE 9}

Experiment VII

Milk yield of ewes injected $1 . V$. with 5 or $10 I U$ oxytocin before a second hand stripping

\begin{tabular}{|c|c|c|c|c|c|c|c|c|c|}
\hline \multirow{2}{*}{\multicolumn{2}{|c|}{$\begin{array}{l}\text { Pre-experimental } \\
\text { period daily yield } \\
\text { (ml) }\end{array}$}} & \multirow[b]{2}{*}{ SE } & \multicolumn{4}{|c|}{ Experimental period } & \multirow{2}{*}{$\begin{array}{l}\text { Post- } \\
\text { experimental } \\
\text { period daily } \\
\text { yield (ml) }\end{array}$} & \multirow[b]{2}{*}{ SE } & \multirow[b]{2}{*}{ SP } \\
\hline & & & $\begin{array}{c}\text { Total daily yield } \\
\text { (residual milk } \\
\text { included }(\mathrm{ml})\end{array}$ & SE & $\begin{array}{l}\text { Residual milk } \\
\text { after oxytocin } \\
\text { (ml) }\end{array}$ & $\mathrm{SE}$ & & & \\
\hline $\begin{array}{r}5 \text { IU group . . } \\
10 \text { IU group .. }\end{array}$ & $\begin{array}{l}628.7 \\
681.7\end{array}$ & $\begin{array}{l}10.7^{*} \\
10.4^{*}\end{array}$ & $\begin{array}{l}729.5 \\
730.4\end{array}$ & $\begin{array}{l}7.4 \\
8.9\end{array}$ & $\begin{array}{l}206.6 \\
204.9\end{array}$ & $\begin{array}{r}10.4 \\
8.8\end{array}$ & $\begin{array}{l}572.5 \\
579.6\end{array}$ & $\begin{array}{l}18.5 \\
19.3\end{array}$ & ** \\
\hline
\end{tabular}

SP $=$ Statistical significance between the three periods.

* $=5$ p. $100>\mathrm{P}>1$ p. 100 .

** $=\mathrm{P}<1$ p. 100 . 
oxytocin stimulation of milk secretion in ewe at the doses used. When we applied the half-udder technique, increases led us to conclude that oxytocin had a mainly peripheral effect on secretion.

\section{Do oxytocin and milk removal locally affect the mammary gland}

Injecting oxytocin between milkings without removing ejected milk stimulates milk secretion in cow, provided that residual milk is extracted with ro $+5 \mathrm{IU}$ of oxytocin after each normal milking. This tonic effect of oxytocin between milkings in cow is relatively low ( $+6 \mathrm{p}$. Ioo) as compared to the effect of extracting residual milk (Io +5 IU) after each milking (+ I4 p. IOo) (MORAG, Ig66). However the galactopoietic effect observed by MORAG (I968) in cow has not been shown in ewe (Experiment III) nor in goat (LINZELL and PEAKER, I97I $a$ ). The specificity of this weak galactopoietic effect might be imputed to the size of the cistern allowing milk storage between milkings. However, this explanation cannot be retained. In Saanen breed goats used by LINZELL and PEAKER (I97I $b$ ) the volume of cisternal milk was much larger than in Préalpes ewes; it represented at least $50 \mathrm{p}$. Ioo of the total content of the goat mammary gland.

The response of cow to oxytocin (MORAG, I968 $b$ ) could explain why the yield of those milked three times a day was higher than those milked twice a day. The same argument, although negative, could be used for ewe. There was no secretory response to oxytocin injected between milkings, and ewes milked three times a day produced about the same amount of milk as those milked twice a day (MoraG, I968 $a$; Denamur and Martinet, unpublished data).

Removal of residual milk ejected by exogenous oxytocin (as opposed to the effect of oxytocin per se) stimulates milk secretion in ewe (Experiments IV, V, VI, VII). Thus, the mere removal of this milk seems to stimulate milk secretion in this species. LINZELI and PEAKER (I97 $a$ ), who did not obtain any effect by massaging the transplanted gland, pointed out the importance of milk removal effect in goats. TURNER (I955) clearly demonstrated the importance of the quality of milk extraction in experiments determining milk production. This extraction effect was emphasized by LINZELL, and PEAKER (I97I $a$ ).

Oxytocin injected every day in cows does not cause any changes in milk production when the glands are catheterized, $i . e$. in under-milking conditions (MIELKE) and BRABANT, 1963) or when an injection is given between milkings (CAROLL, et al., I968). Some cases of inhibition of normal secretion may even be noticed when the mammary gland is under-milked (GRAF et al., I973). However, when using a dose exceeding $20 \mathrm{IU}$ followed by immediate complete extraction of milk, yield increase ranges between 5 and $20 \mathrm{p}$. IOo (KNODT and PETERSEN, 1944).

The importance of milk emptying with a view to demonstrating oxytocin effect on milk secretion is even more obvious in species having no cisterns for storage of part of the ejected milk. Using identical doses of oxytocin in mouse, suckling by the young leads to yield increase (CARUoL,, I97I), whereas the same treatment without suckling causes noticeable decrease of litter growth (MIzuno and SHIrBa, I969). Oxytocin also increases milk production in rat by $13 \mathrm{p}$. Ioo if milk is extracted after the injection (KUMARASAN and TURNER, I966) whereas absence of milk emptying leads to inhibition of secretion (KUHN and MCCANN, I970). 
It may be concluded that oxytocin injected to lactating animals without immediate milk extraction inhibits secretion; secretion is stimulated if ejected milk is removed immediately.

The mammary gland appears to have two regulatory phenomena depending on both oxytocin and gland vacuity. Whatever the oxytocin blood level, if the gland is not emptied by young or by milking, secretion is inhibited more or less rapidly. Oxytocin cannot affect mammary RNA level in absence of milk emptying (GRIFFITH and TURNER, I962). If the mammary gland is emptied after being stimulated by the young, oxytocin release as well as milk secretion stimulation are observed, corresponding to the dietary requirements of the young (onset of lactation).

If exogenous oxytocin is added to endogenous oxytocin at a dose close to the physiological level of the animal, the normally observed stimulation of milk secretion is enhanced. This oxytocin stimulation of milk secretion, only appearing when the gland is emptied, has been studied in vitro. It was demonstrated that oxytocin markedly accelerates the expulsion of synthesized caseins from the mammary cells (OlLIVIER-Bousquet, unpublished data). These experiments on the intracellular migration rate of secretory products seem to the first step towards an explanation of the role of oxytocin in mammary cell secretion.

\section{Does oxytocin inhibit normal milk ejection}

Exogenous oxytocin generally injected in doses higher than the physiological level seems to inhibit normal milk ejection in cow (CAROLL et al., I968), sheep (MORAG and Fox, I966), and rat (KUHN and McCANN, 1970). We observed a similar effect (Experiments III, IV, V, VI), i.e. in most cases total milk and residual milk increased and the amount of milk normally extracted by machine decreased. It was assumed that inhibition occurred via a feedback mechanism thus impeding oxytocin release during milking (MENA et al., I974). DEIS (I97I) studying rat, showed that injecting large doses of oxytocin brings about milk ejection inhibition. This inhibition reaches a maximum 90 minutes later but does not seem to be maintained. MENA et al. (1974) suggested the inhibition caused by high oxytocin doses (I60 $\mathrm{m}$ IU to $4 \mathrm{IU}$ ) might be imputed to the effect of the sympathetic nervous system on mammary myoepithelium.

In these different experiments it is difficult to determine whether inhibitory effect depends on a drop in secretion due to inefficient emptying of the milk secreted, or whether the secretion itself merely drops.

Further study will determine if various doses of exogenous oxytocin affect endogenous oxytocin blood level induced by physiological stimulation.

Flow rate measurements, on the other hand, furnish some information on this inhibition during milking (Experiment VII). In most cases, cisternal milk is reduced by exogenous oxytocin. Milk ejected by endogenous oxytocin is also reduced, especially in the Io IU group, i.e. second peak milk. In our experimental conditions regular injecsion of oxytocin after machine milking and before extraction of residual milk seems to inhibit accumulation of cisternal milk between milkings and milk ejection. Repeated oxytocin injection after each milking definitely leads to residual milk increase. However, this increase cannot be imputed to an inhibition of either myoepithelial or hypophyseal origin. 


\section{Do high doses of oxytocin have a special effect on milk yield}

Preliminary experiments in Préalpes ewes showed that lactation rapidly ceased with large doses of oxytocin (Denamur, Boccard, Ricordeau and Martinet, unpublished data). Similarly the group of ewes in Experiment IV receiving 5 IU of oxytocin yielded less milk than those given saline.

In Experiment VII ewes receiving 5 and Io IU produced similar amounts of milk, and both groups yielded much more than when no oxytocin was given. Ewes of the English breed reacted similarly to small (MorAG and Fox, I966) and large (Experiment VI) doses. In both cases, oxytocin administration and subsequent removal of residual milk caused an increase in milk yield of some $25 \mathrm{p}$. roo and a sharp increase in the relative size of the residual fractions. These effects seemed to be independent of dose level (5 IU versus Io IU). We were unable to explain the breed discrepancy or why Préalpes ewes reacted differently to high doses in Experiments IV and VII. The experimental data on the effect of supraphysiological doses of oxytocin given to lactating animals seemed to depend on whether or not milk was extracted after the injection.

In experiments on small rodents (Mizuno and SHIBA, I969; MENA and BEyER, I969; KUHN and MCCANN, I970) the mammary gland is probably not well emptied by the young, as these females do not have a cisternal system comparable to that of ewe, goat and cow which stores the milk ejected. In rat, even when milk emptying occurs immediately after oxytocin injection (Mizuno and SATOH, 1970), total milk yield increases (normal milk + residual milk). As emphasized above, whatever the animal species, the amount of residual milk always increases after injection of high doses of oxytocin (Donker et al., I954; CARoli et al., I968; Mizuno and Satoh, I970).

$$
\text { Reçu pour publication en avril } 1976 .
$$

\section{RÉSUMÉ}

\section{RÔLE DE L'OCYTOCINE EXOGENNE CHEZ LA BREBIS EN LACTATION}

Dans une série d'expériences sur brebis laitière, les auteurs tentent d'analyser le rôle de l'acytocine exogène sur la sécrétion laitière.

Exp. I et II. L'injection de dose non galactokinétique (o,or et $0,05 \mathrm{UI} /$ heure) introcarotidienne ne modifie pas la production laitière. Ces résultats semblent écarter la possibilité d'une activité centrale de l'ocytocine sur la libération d'un complexe hormonal lactogène hypophysaire.

Exp. III, IV et $V$. L'ocytocine (o, I ̀̀ 2 UI) injectée par voie intraveineuse ne se révèle tonique sur la lactation que si son injection est suivie de l'extraction du lait résiduel qu'elle a mobilisé.

Les expériences III, IV, VI et VII confirment le rôle tonique de l'ocytocine sur la sécrétion du lait, même lorsqu'elle est injectée à forte dose (o, I à Io UI) par voie intraveineuse après chaque traite. A ce rôle tonique s'ajoute un effet inhibiteur sur l'éjection naturelle.

\section{REFERENCES}

Benson G. K., Folley S. J., r956. Oxytocin a stimulator for the release of prolactin from anterior pituitary. Nature (London), 177, 7oo.

Benson G. K., Folley S. J., I957. The effect of oxytocin on mammary gland involution in the rat. J. Endocr., 16, I89-202. 
Bryant G. D., Greenwood F. C., Linzell J. L., rg68. Plasma prolactin levels in the goat : physiological and experimental modification. J. Endocr., 40, IV-V.

Bryant G. D., Linzell J. L., GReenwood F. C., I970. Plasma prolactin in goats measured by radioimmunoassay : the effects of teat stimulation, mating behavior, stress fasting and of oxytocin, insulin and glucose injections, in Hormones, vol. 1, 26-35, S. Karger ed., Basel.

Carold, E. J., Jacobsen M. S., Kassouny M., Smith N. E., Armstrong D. T., I968. An inhibitory effect of oxytocin on the milk ejection reflex. Endocrinology, 82, 179-182.

Caruolo E. V., I971. Exogenous oxytocin and lactation in the mouse. J. Dairy Sci., 54, I207-I2Ir.

Cohen J., Brenneman A. R., Topper Y. J., I962. The stimulation by oxytocin and acetylcholine on glucose oxidation by lactating rat. Mammary-gland slices : inhibition of the hormone effect by puromycin. Bioch. Biophys. Acta, 63, 554-556.

Deis R. P., I97ı. Inhibition of milk ejection by exogenous oxytocin in lactating rats. Proc. Soc. Exp. Biol. Med., 137, , 1006-1or2.

Denamur R., r953. Action de doses répétées d'ocytocine sur la sécrétion du lait chez la Chèvre. C. $R$. Soc. Biol., 147, 88-92.

Denamur R., Martinet J., I96r. Action de l'ocytocine sur Ia sécrétion du lait de brebis. Ann. Endocr., 22, 776-781.

Denamur R., Martinet J., i97o. Nature des hormones ante-hypophysaires stimulantes de la sécrétion lactée chez la Brebis normale. Arch. Intern. Pharmaco-Thérapie, 186, I85-I87.

Donker J. D., Koshi J. H., Petersen W. E., I954. The effect of exogenous oxytocin in blocking the normal relationship between endogenous oxytocic substance and the milk ejection phenomenon. Science, 119, 67-68.

Elliot G. M., 1959. The direct effect of milk accumulation in the udder of the dairy cow upon milk secretion rate. Dairy Sci. Abstr., 21, 435-439.

Elliotr G. M., I959. The effect on milk yield of the length of milking intervals used in twice a day milking, twice and three times a day milking and incomplete milking. Dairy Sci. Abstr., 21, 48I-49o.

GoOdFriend T. L., Topper Y. J., I96r. Effects of oxytocin, vasopressin and acetylcholine on glucose metabolism in mammary tissue in vitro. J. Biol. Chem., 236, $124 \mathrm{I}-\mathrm{I} 243$.

Graf G. C., Elliot C. S. Jr., Randy H. A., Jr, I973. Inhibition effect of continuous infusion of oxytocin on lactation in cows. J. Dairy Sci., 56, $181-183$.

Griffith D. R., TuRNer C. W., 1962. Hormonal Control of mammary gland involution in the rat. Proc. Soc. Exp. Biol. Med., 110, 485-487.

Knodt C. B., Petersen W. E., I944. The effect of complete evacuation of the mammary gland by pitocin upon milk and fat production. J. Dairy Sci., 27, 449-457.

Knutsson P. G., I96I. Permeability of the mammary gland to sodium 24, potassium 42, chlorine 36 and iodine I3I. Nature, 192, 977-978.

Kuhn E. R., McCANN S. M., I97o. An inhibitory action of large doses of oxytocin on milk yield in the lactating rat. Endocrinology, 87, I266-1273.

Kumarasan P., Turner C. W., 1966. Effect of oxytocin upon litter weight gain in rats. Proc. Soc. Exp. Biol. Med., 123, 70-72.

Labussière J., Martinet J., ig64. Description de deux appareils permettant le contrôle automatique. des débits de lait au cours de la traite à la machine. Premiers résultats obtenus chez la Brebis. Ann. Zootech., 13, 199-212.

Labussikte J., Martinet J., Denamur R., I969. The influence of the milk ejection reflex on the flow rates during milking of ewes. J. Dairy Res., 36, I9I-20I.

Lévy H. R., I963. Inhibition of mammary gland acetyl CoA carboxylase by fatty acids. Biochem. Biophys. Res. Comm., 13, 267-272.

Linzell J. L., PeAKer M., 197r. The effects of oxytocin and milk removal on milk secretion in the goat. J. Physiol., 216, 7І7-734.

Linzell J. L., Peaker M., I97I. Permeability of mammary ducts in the lactating goat. J. Physiol., 213, 48-49 p.

Linzell J. L., Peaker M., I97I. Intracellular concentrations of sodium, potassium and chloride in the lactating mammary gland and their relation to the secretory mechanism. J. Physiol., 216, 683-70o.

Mackenzie D. D. S., LAscelles A. K., I965. The variation in the composition of milk during successive stages of milk removal from the mammary gland of the cow. Austr. J. Biol. Sci., 18, 379-386.

Martinet J., Denamur R., I960. Étude préliminaire des mécanismes de l'évacuation du lait de la glande mammaire chez la Chèvre et la Brebis. Arch. Sci. Physiol., 14, 35-96.

Meites J., I958. Ability of hormones to extend lactation and prevent mammary involution in parturient rats after removal of litters. J. Anim. Sci., 17, 1223.

Meites J., NiCOLL O.S., r959. Hormonal prolongation of lactation for 75 days after litter withdrawal in post partum rats. Endocrinology, 65, 572-579.

Mena F., Beyer C., 1969. Effect of large doses of oxytocin on milk secretion in intact and spinal cord transected rats. Physiologist, 12, 300.

Mena F., Beyer C., Grosvenor C. E., I974. On the mechanism by which oxytocin depresses milk ejection and milk secretion in rats. Amer. J. Physiol., 227, 1249-1254. 
Mielke H., Brabant W., I963. Lactogenese und Galaktopoese beim Rind ohne Saug, Melk-oder andere exogene, zur Milchejektion führende Euterreize. Arch. Exp. Vet.-Med., 16, 909-9I9.

Mizuno H., SAToH K., I97o. Further studies on inhibition of milk ejection by administration of oxytocin to the mouse. Endocr. Jap., 17, 15-22.

Mizuno H., ShiıA N., I969. Inhibitory effect of oxytocin administration on lactationin mice. Endocr. Jap., 16, 547-553.

Morag M., 1967. A galactopoietic role of oxytocin in the cow. Life Sci., N. Y., 6, I5I3-1518.

Morag M., I968. The effect of regular intravenous injection of oxytocin at milking time on the proportion of the yield obtained as residual milk in the ewe. J. Dairy Res., 35, 377-38r.

MorAG M., 1968. A galactokinetic effect from oxytocin administered between milkings in the cow. Ann. Biol. Anim. Bioch. Biophys., 8, 27-43.

Morag M, Fox S., I966. Galactokinetic responses to oxytocin in the ewe. Ann. Biol. Anim. Bioch. Biophys., 6, 467-478.

MoraG M., Griffin T. K., I968. Galactokinetic responses to oxytocin and other solutions in the cow. Ann. Biol. Anim. Bioch. Biophys., 8, 235-247.

MoraG M., Brick D., I969. The stimulation and inhibition of milk secretion by oxytocin in the rat. Life Sci. (N. Y.), 8, 143-150.

Ollivier-Bousquet M., I976. Effet de l'ocytocine in vitro sur le transit intracellulaire et la secrétion des proteines dn lait. C. R. Acad. Sc. Paris, D, 282, 13-16.

Turner H. G., I955. Sources of variation in residual milk and fat in dairy cows, their relation to secretion rates and persistency of lactation. Austr. J. A gric. Res., 6, 515-529.

WheElock J. V., Rook J.A. F., Dodd J. H., Griffin T. K., I966. The effect of varying the inter* val between milkings on milk secretion. J. Dairy Res., 38, I61-1>6. 